\title{
Gondolatok a krónikus koronária szindróma ESC ajánlásának hazai alkalmazásáról
}

\author{
Tomcsányi János ${ }^{1}$, Jánosi András², Turi-Kováts Nóra' \\ ${ }^{1}$ Betegápoló Irgalmasrendi Kórház, Kardiológia, Budapest \\ ${ }^{2}$ Gottsegen György Országos Kardiológiai Intézet, Nemzeti Szívinfarktus Regiszter, Budapest
}

Levelezési cím: Dr. Turi-Kováts Nóra, 1027 Budapest, Árpád fejedelem útja. 7. E-mail: turi-kovats@hotmail.com

A stabil koronáriabetegség az a kórkép, amelynek diagnózisa és kezelése a legtöbb beteget és orvost érinti. Az is biztonsággal állítható, hogy mind a diagnózis, mind a kezelés területén igen sok a lezáratlan kérdés, hiányoznak az evidenciák.

Érthető ezért, hogy nagy érdeklődés kísérte az egyik legrégebbi európai szakmai ajánlás megújult változatát (1). Már csak azért is vártuk nagyon az ajánlást, mert számos újabb vizsgálati eredményről, kivizsgálási és kezelési módszerröl jelentek meg közlemények. Az új ajánlás nagyban eltér a korábbi ajánlástól, ezért érdemes kritikusan végignézni, hogy mik azok az újdonságok, amik elörelépést jelentenek, és mik azok, amik kérdéseket vetnek fel, és/vagy aggodalomra adnak okot. Elöljáróban szeretnénk hangsúlyozni, hogy a közlemény szerzői elkötelezett "guideline hívők és hirdetők", kritikai megjegyzéseink döntően az útmutató hazai gyakorlati alkalmazhatóságának pontjait érintik.

\section{Nomenklatúra, klasszifikáció}

Logikus és didaktikus az új nomenklatúra. Régi tapasztalat, hogy a koszorúér-betegség heveny és krónikus klinikai formái sok esetben egymást követik, illetve ugyanaz a klinikai scenario a beteg élete folyamán többször ismétlődhet. Az ajánlás akut koronária szindróma mellett leírja a krónikus koronária szindrómát, azonban nem tesz az elnevezés mellé egy jól körülhatárolt definíciót, hanem CCS-ben az alábbi 6 féle klinikai megjelenési formát határozza meg:

1. Stabil angina és/vagy dyspnoe.

2. Új keletủ szívelégtelenség vagy balkamra-diszfunkció hátterében feltételezett koronáriabetegség.
3. ACS vagy revaszkularizáció után egy éven belül szimptómás és aszimptómás beteg.

4. Diagnózis/revaszkularizáció után több mint egy évvel, függetlenül a szimptomatikától.

5. Angina, ahol vazospazmus vagy mikrovaszkuláris etiológia feltételezhető.

6. Aszimptómás, szűréssel diagnosztizált koronáriabeteg.

Az egységes szemléletböl következik, hogy egy nagyon heterogén betegcsoportot sikerült egy nomenklatúra alá behelyezni. A 6 . forgatókönyv esetében nem lehet tudni, hogy mi a különbség a koronáriabetegség és CCS között. Szerintünk az aszimptómás koronáriabeteg nem szindróma, és ezért nem illik ebbe a betegcsoportba. A CCS nagyon eltérő klinikai formái alapján nyilvánvaló, hogy egységes diagnózis és kezelés nem jön szóba. Mindezek elörebocsájtása után részletesebben a stabil angina diagnózisának és kezelésének kérdéseivel foglalkozunk.

\section{Diagnosztika}

Az útmutató sorrendben első, új ajánlása arról szól, hogy tünetekkel jelentkező betegek esetén a koszorúér-betegség diagnózisa, illetve a myocardium-iszkémia igazolása képalkotó eljárással történjen abban az esetben, ha a koszorúér-betegség kizárása a klinikai adatok alapján nem lehetséges. Ha az ajánláshoz tartozó folyamatábrát megnézzük, akkor nyugalmi EKG-t követően lényegében a CCTA az a vizsgálat, amivel az obstruktív koszorúér-betegség diagnózisának igazolása vagy kizárása történik. Amennyiben koszorúér-betegség mellett szól a CCTA, akkor képalkotó eljárással 
vizsgáljuk a myocardiumiszkémiát, és ennek eredménye határozza meg a további teendőket. Érdekessége az ajánlásnak, hogy a diagnosztikus vizsgálatok (laboratóriumi vizsgálatok, nyugalmi EKG, mellkasröntgen, szívultrahang, Holter-vizsgálat) tekintetében különböző szintű és erősségű ajánlást tartalmaz. A terheléses EKG szövegszerü említése olyan formában történik, hogy gondolni lehet a vizsgálatra (Ilb szintủ ajánlás), ha a noninvazív vagy invazív képalkotó vizsgálatra nincs lehetőség, vagy ha a terhelési toleranciát vagy terhelésre jelentkező aritmiát akarjuk vizsgálni.

A terheléses EKG - ami véleményünk szerint méltánytalanul alulértékelt a jelen útmutatóban - később előkerül a 3. táblázatban, ami a koszorúér-betegség preteszt valószínűségének (PTP) meghatározásának szempontjait tárgyalja. A normális terheléses EKG csökkenti, a kóros növeli a PTP-t. Ezzel csak az a gond, hogy a jelen útmutató lehetőségként kezeli a vizsgálat elvégzését, de kihagyta az ajánlott diagnosztikai eljárások közül. Számos adat szerint a terheléses EKG - korlátozott diagnosztikus értéke ellenére, vagy annak ismeretében - napjainkban is az egyik leggyakrabban elvégzett noninvazív kardiológiai vizsgálat.

1. Előbbre helyezi a társbetegségek meghatározását, mint hogy a betegnél érdemi kivizsgálás történne ( $F i$ gure 2, ESC CCS Guideline, 2019). Így részben nem számol az egyes újkeletü betegségekkel (pl. diabétesz, veseelégtelenség), illetve nem tudni, hogy mi a panaszokat okozó alapbetegség és mi a társbetegség (pl. GERD versus stenocardia).

A kivizsgálás formáját, hasonlóan az előző ajánláshoz, preteszt valószínúség alapján javasolja úgy, hogy a legnagyobb betegszámot kitevő alacsony-közepes valószínűségű betegeknél a coronaria $\mathrm{CT}$-angiográfiát teszi az első helyre. A kiindulási pont az volt, hogy a feltételezett stabil angina preteszt valószínűsége sokkal alacsonyabb, mint azt korábban feltételezték, ezért ennek kizárására a koronária CT-angiográfia a legalkalmasabb. Ez több problémát is felvet. Az első, hogy egy olyan vizsgálatra hivatkoznak (2), ahol alacsony betegszám és viszonylag korai élekor szerepel (30 éves kórtól vontak be dán betegeket). Miért gondoljuk, hogy 3648, 30 évnél idősebb dán egyén jól reprezentálja a teljes európai anginás betegpopulációt? Nem beszélve a közép-kelet európai betegpopulációról. A másik, hogy a napi életben Európa legtöbb országában ez teljességgel megvalósíthatatlan (Dániában is csak kevesebb, mint a betegek felénél történt CCTA a fent idézet vizsgálatban). Ennek igazolására megkérdeztük a magyarországi CCTA-t végző helyeket, hogy egy beteg CCTA-vizsgálatára mennyi a várakozási idő. A kapott válaszokat az 1. táblázat szemlélteti. Jelenleg Magyarországon az átlagos várakozási idő adataink szerint közel két hónap (58 nap) a szakorvosi vizsgálattól számítva, ugyanis családorvos CCTA-ra nem küldhet beteget. 2. Milyen várakozási időket jelentene, ha minden alacsony-közepes rizikójú beteget a terheléses EKG helyett CCTA-ra küldenénk?! A harmadik probléma, hogy az iniciális CCTA csak az obstruktív koronáriabetegség anatómiájáról nyilatkozik. Ezzel még nem zárható ki az, hogy a terhelésre mellkasi fájdalomról beszámoló betegnek iszkémiás szívbetegség okozza a panaszait, mivel az iszkémiás szívbetegség az nem egyenlő az obstruktív koronáriabetegséggel, amit egyébként az ajánlás nagyon helyesen hangsúlyoz is.

\begin{tabular}{|c|c|c|c|c|}
\hline Település & Kórház & Időpontkérés & Időpont & Várakozási idő (nap) \\
\hline Budapest & SE VSZÉK & okt. 11. & máj. 28. & 230 \\
\hline Budapest & Bajcsy Kórház & okt. 10. & dec. 30 . & 81 \\
\hline Budapest & MH II. sz. telephely (MÁV) & okt. 11. & dec. 17. & 67 \\
\hline Budapest & Péterfy Kh. & okt. 09. & dec 02. & 54 \\
\hline Békéscsaba (Békés) & Békés Megyei Központi Kórház & okt. 09. & okt. 22. & 13 \\
\hline Debrecen (Hajdú-Bihar) & DE Radiológia & okt. 11. & dec. 02 . & 52 \\
\hline Eger (Heves) & Markhot Ferenc Kórház Radiológia & okt. 10. & nov. 30 . & 51 \\
\hline Győr (Györ-Moson-Sopron) & Affidea Győr & okt. 09. & nov. 27. & 49 \\
\hline Kaposvár (Somogy) & SM KMOK Diagnosztikai Központ & okt. 09. & okt. 28. & 19 \\
\hline Pécs (Baranya) & PTE Radiológia & okt. 11. & jan. 10. & 91 \\
\hline Salgótarján (Nógrád) & Diagnoscan Salgótarján & okt. 11. & okt. 25. & 14 \\
\hline Sopron (Győr-Moson-Sopron) & Soproni Erzsébet Oktató Kórház & okt. 11. & dec. 12. & 62 \\
\hline Szeged (Csongrád) & Affidea Szeged & okt. 11. & dec. 20 . & 70 \\
\hline Szekszárd (Tolna) & TMK Balassa János Kórház & okt. 09. & okt. 28. & 19 \\
\hline Székesfehérvár (Fejér) & Szt. György Diagnosztikai Központ & okt. 10. & nov. 08. & 29 \\
\hline \multirow[t]{2}{*}{ Szombathely (Vas) } & Markusovszky Kórház & okt. 11. & nov. 14 & 34 \\
\hline & & & Átlag: & 58,4375 \\
\hline
\end{tabular}


3. Az iniciális diagnosztikai vizsgálatok megválasztására egy nagy és szemléletes ábrát használ (Figure 4, ESC CCS Guideline, 2019), ahol a noninvazív vizsgálatoknál hangsúlyozza a helyi feltételek és szakértelem meglétét, az invazív vizsgálatoknál azonban nem fektet erre hangsúlyt. Logikátlan továbbá az is, hogy bár lehetségesnek tartja iniciális vizsgálatnak az invazív koronarográfiát, de csak akkor, ha a beteg terápiarefrakter, vagy alacsony a terheléses EKG-küszöb (ami egyébként nem is szerepel a kivizsgálási algoritmusban), vagy csökkent a balkamra-funkció. Tehát minden feltétel egy már korábbi diagnózishoz, illetve noninvazív vizsgálathoz kötött, nagyon helyesen, ez esetben azonban nem tekinthető elsődleges vizsgáló módszernek.

\section{Terápia}

1. A terápia részben is számos feloldandó ellentmondás, vitatható rész van. Ezek körül talán a napi gyakorlatban is legfontosabbak az antiiszkémiás kezelésnél találhatók. Üdvözlendő, hogy az ajánlást írók megállapítják, hogy egyénre szabott antiiszkémiás kezelést kell alkalmazni, és nincsen egységesen elfogadott optimális gyógyszeres kezelés, hanem azt adaptálni kell a betegre. A standardterápia mellett négy betegcsoportot különítenek el a CCS-betegek kezelésére aszerint, hogy milyen a vérnyomás, pulzus és balkamra-funkció. (Már itt sem érthető, hogy a posztinfarktusos/posztrevaszkularizált betegek miért nem kapnak egy külön csoportot). Továbbra is a lépcsőzetes kezelési stratégiát javasolják úgy, hogy az elsővonalbeli készítmények mindig a béta-blokkolók és/vagy kalciumantagonisták, és a másodvonalbeliek legtöbbször a hosszú hatású nitrátok. Így fordulhat az elő, hogy hipotóniás betegnél is kis dózisú béta-blokkoló vagy kalciumantagonista után hosszú hatású nitráttal való kombinációt javasol. Ez több szempontból is aggályos:

- semmilyen tartós hatású nitráttal végzett vizsgálat nem volt hipotóniás betegpopulációra (3).

- A hipotóniás betegpopulációban adott tartós hatású nitrát tovább fokozza a hipotenziót, ami növeli a várható kardiovaszkuláris eseményék számát $(4,5)$. - Semmilyen vizsgálat nem igazolta, hogy tartós hatású nitrát hatásosabb másodvonalbeli készítmény lenne, mint a többiek. Sőt a trimetazidin és a ranolazin (nálunk nem forgalmazott készítmény) effektívebbnek bizonyult egy újabb metaanalízisben, mint a tartós hatású nitrátok (6).

2. A prevenciós terápiáknál számos újdonság beke- rült az ajánlásba, ami az antitrombotikus kezelésre vonatkozik. Az is üdvözlendő, hogy a CCS-ben az agresszív statin szerepét hangsúlyozza. Ugyanakkor érthetetlen, hogy amíg a statinkezelésnél arra hivatkozik, hogy a CCS egy igen magas kardiovaszkuláris rizikójú betegcsoport, addig az ACE-gátlók preventív alkalmazásánál ezt csak, mint opciót adják meg. Ugyancsak kedvező újdonság, hogy a CCS és diabétesz esetén mind az SGLT2-inhibitorok, mind a GLP1-receptor-antagonisták IA ajánlással szerepelnek.

\section{Ko̊vetkeztetések}

Véleményünk szerint a szóban forgó ajánlás a legtöbb európai országban nagy valószínüséggel nem kivitelezhető, Magyarországon jelenleg biztosan megvalósíthatatlan. Az ajánlás egy útmutató, célszerűnek tartjuk a hazai diagnosztikai útvonal újratervezését az ismert feltételek figyelembevételével elsősorban annak érdekében, hogy a mellkasi fájdalommal jelentkező betegek időben diagnózishoz és adekvát kezeléshez jussanak. Számos ponton vitathatók a gyógyszeres kezelésre vonatkozó megállapítások, amiket sokszor semmilyen vizsgálat nem támaszt alá. Leírt gondolataink célja felhívni a figyelmet az ajánlásra, javasoljuk az útmutató részletes tanulmányozását, kritikai értékelését és alkalmazását.

\section{Irodalom}

1. Knuut J, Wijns W, Saraste A, Capodanno D, Barbato E, et al. 2019 ESC Guidelines for the diagnosis and management of chronic coronary syndromes. The Task Force for the diagnosis and management of chronic coronary syndromes of the European Society of Cardiology (ESC). Eur Heart J 2019 doi: 10.1093/eurheart/ehz 425

2. Reeh-J, Therming CB, Heitmann M, et al. Prediction of obstructive coronary artery disease and prognosis in patients with suspected stable angina. Eur Heart J 2018; 40: 1426-1435. doi: 10.1093/ eurheartj/ehy806

3. Wei J, Wu T, Yang Q, et al. Nitrates for stable angina: A systemic review and metaanalysis of randomized clinical trials. Int J Cardiol 2011; 146: 4-12. doi: 10.1016/j.ijcard.2010.05.019

4. Belsey J, Savelieva I, Mugelli A, et al. Relative efficacy of antianginal drugs used as add-on therapy in patients with stable angina: A systemic review and metaanalysis. Eur J of Preventive Cardiol 2015; 22(7): 837-848. doi: 10.1177/2047487314533217

5. Bangalore-S, Messerli FH, Franklin SS, et al. Pulse pressure and risk of cardiovascular outcomes in patients with hypertension and coronary artery disease: anINternational VErapamil SR-trandolapril STudy (INVEST) analysis. Eur Heart J 2009; 30(11): 1395-1401. doi: 10.1093/eurheartj/ehp109

6. Owens $\mathrm{P}, \mathrm{O}$ 'Brien $\mathrm{E}$. Hypotension in patients with coronary disease: can profound hypotensive events cause myocardial ischaemic events. Heart 1999; 82: 477-481. doi: 10.1136/hrt.82.4.477 